\title{
PERAN ALTERNATIF PENYELESAIAN SENGKETA DI LUAR PENGADILAN DALAM PERLINDUNGAN DAN PENGELOLAAN LINGKUNGAN HIDUP
}

\author{
Agnes Grace Aritonang \\ Program Pascasarjana Fakultas Hukum, Universitas Indonesia \\ Universitas Indonesia Kampus Salemba, JI. Salemba Raya No. 4 Jakarta Pusat 10430 \\ agnesgrace16@gmail.com/ agnes.grace91@ui.ac.id
}

\begin{abstract}
The relationship between the environment and humans is a unity to achieve the balance of the universe. Sustainable development that is environmentally sound is a reflection of the prosperity of the people. Humans are encouraged to achieve satisfaction and prosperity through arbitrary exploitation of nature with the act of heeding environmental sustainability. The case of environmental pollution that never ends proves the weakness of law enforcement officers in Indonesia. The public no longer trusts dispute resolution through the courts due to the complexity of the bureaucracy. Regarding environmental disputes that are not resolved through the courts, the community is given a choice through non-litigation or out of court, which can be reached by mediation, conciliation, or arbitration mechanisms. The non-litigation path that presents informality mechanisms such as deliberation to reach a final agreement is considered capable of being the best solution for resolving environmental disputes for the community.
\end{abstract}

Keywords: Natural Resources Exploitation; Environmental Disputes; Dispute Resolution Outside The Court

\begin{abstract}
Abstrak
Hubungan antara lingkungan hidup dengan manusia merupakan satu kesatuan untuk mencapai keseimbangan alam semesta. Pembangunan berkelanjutan yang berwawasan lingkungan menjadi cerminan kemakmuran rakyat. Manusia didorong untuk mencapai kepuasan dan kemakmurannya melalui eksploitasi alam yang semena-mena dengan tindak mengindahkan kelestarian lingkungan hidup. Kasus pencemaran lingkungan hidup yang tidak kunjung usai membuktikan lemahnya aparat penegak hukum di Indonesia. Jalur penyelesaian sengketa melalui pengadilan tidak lagi dipercayai oleh masyarakat akibat rumitnya birokrasi. Terhadap sengketa lingkungan yang tidak terselesaikan melalui jalur pengadilan, masyarakat diberikan pilihan melalui jalur non litigasi atau di luar pengadilan yang dapat ditempuh dengan mekanisme mediasi, konsiliasi, maupun arbitrase. Jalur non litigasi yang menghadirkan mekanisme informalitas seperti musyawarah mufakat guna mencapai suatu kesepakatan akhir, dinilai mampu menjadi solusi terbaik penyelesaian sengketa lingkungan hidup bagi masyarakat.
\end{abstract}

Kata kunci: Eksploitasi Sumber Daya Alam; Sengketa Lingkungan Hidup; Penyelesaian Sengketa di Luar Pengadilan

\section{A. Pendahuluan}

Sumber daya alam berlimpah yang dimiliki oleh Indonesia kian hari semakin mengalami penurunan kualitas dan kuantitas akibat perkembangan ilmu pengetahuan dan teknologi yang 
digunakan tidak pada tempatnya. Ilmu pengetahuan dan teknologi yang seharusnya diharapkan menjadi sarana pengembang dan pelestari alam, justru menjadi alat perusak akibat tindakan eksploitasi semena - mena dan tingginya tingkat pembangunan industri kelas berat untuk memenuhi standar kebutuhan hidup manusia ${ }^{1}$. Sebagaimana yang dikemukakan oleh Agus Purnomo bahwa antara manusia dengan alam secara filosofis saling memiliki keterkaitan. Dalam satu pandangan, manusia diyakini sebagai seorang pemilik juga pengambil seluruh manfaat yang dimiliki oleh bumi dan menguasai segenap kehidupan di bawah di atasnya, sedangkan pandangan yang lainnya meyakini bahwa manusia itu seyogyanya adalah bagian dari alam semesta ${ }^{2}$.

Hubungan antara manusia dengan lingkungan hidup harus saling timbal balik dengan tetap menjaga keselarasan, keseimbangan dan keserasian sebagaimana yang diamanatkan dalam Pasal 33 ayat (3) UUD 1945 yang mewajibkan agar seluruh sumber daya alam di bumi ini dipergunakaan sebesar-besarnya untuk kemakmuran rakyat ${ }^{3}$. Salah satu bentuk perwujudan kemakmuran rakyat yang dimaksud adalah dengan pelaksanaan pembangunan secara berkelanjutan (sustainable development). Dengan pembangunan berkelanjutan yang berwawasan lingkungan, diharapkan ada daya dukung terhadap seluruh kegiatan pembangunan agar selalu terjaga dan seimbang sehingga nantinya hasil dari pembangunan ini dapat dirasakan oleh seluruh lapisan generasi, baik masa kini maupun masa yang akan datang. ${ }^{4}$

Dalam proses mencapai pembangunan berkelanjutan dengan wawasan lingkungan tersebut, pemerintah Indonesia sendiri telah memiliki suatu komitmen kuat yaitu : Pertama, adanya pengakuan terhadap subjective rights dalam pengelolaan lingkungan sebagaimana yang diatur dalam Pasal $28 \mathrm{H}$ ayat (1) Undang-Undang Dasar Negara Republik Indonesia Tahun 1945; Kedua, mengakui bahwa elemen berwawasan lingkungan adalah hal yang penting dalam menunjang perekonomian nasional sebagaimana diamanatkan dalam Pasal 33 ayat (4) Undang-Undang Dasar Negara Republik Indonesia Tahun $1945 .{ }^{5}$ Amanat lain tersirat dalam Pasal 33 ayat (4) Undang-Undang Dasar Negara Republik Indonesia dimana secara tidak

1 Lili Rasjidi dan I.B. Wyasa Putra, Hukum sebagai Suatu Sistem, (Bandung: CV. Mandar Maju, 2003), hal. 177

2 E. Shobirin Najd et al, Diseminasi Hak Asasi Manusia, Perspektif dan Aksi, (Jakarta: Cesta LP3ES, 2000), hal. 137)

3 Indonesia, Undang-Undang Dasar Negara Republik Indonesia Tahun 1945, Ps 33 ayat (3)

4 Otto Soemarwoto, Analisis Mengenai Dampak Lingkungan, (Yogyakarta: Gajahmada University Press, 2003), hal. 16

5 Jimly Asshiddiqie, Green Constitution (Nuansa Hijau Undang Undang Dasar Negara Republik Indonesia Tahun 1945), (Jakarta : Rajagrafindo Persada, 2009), hal. 6 
langsung pasal ini memberikan penekanan bahwa pembangunan berkelanjutan (sustainable development) merupakan poros utama majunya pembangunan ekonomi suatu negara. ${ }^{6}$

Sejak tahun 1972, pemerintah Indonesia telah memberikan perhatian khusus terhadap pengelolaan lingkungan hidup, yang mana pada tahun yang sama pemerintah Indonesia bergabung dalam Konferensi Lingkungan Hidup Sedunia Pertama yang diselenggarakan pada bulan Juni di Stockholm. Meski pada saat itu Indonesia belum mengenal lembaga khusus yang menangani sengketa lingkungan hidup. Konferensi Stockholm menjadi pencetus motto "Hanya Ada Satu Bumi (Only One Earth)" untuk semua manusia, yang dimana di dalamnya membahas dan mengkaji problematika lingkungan hidup di berbagai belahan dunia. ${ }^{7}$ Melalui konferensi ini, seluruh pemerintahan di dunia diikutsertakan dalam proses penilaian dan perencanaan lingkungan hidup, penggalakan partisipasi masyarakat, menyatukan pendapat dan sikap peduli negara baik yang berkembang maupun yang sudah maju untuk ikut menyelamatkan bumi, dan mengembangkan pembangunan dengan tetap konsisten memelihara lingkungan hidup. ${ }^{8}$

Dalam konferensi ini terdapat dua pandangan yang berkesimpulan bahwa lingkungan hidup yang rusak diakibatkan oleh Negara yang dihuni oleh masyarakat miskin, sedangkan pandangan yang lain mengatakan di saat Negara-negara lainya berambisi untuk melakukan pembangunan terus menerus, disaat itu jugalah lingkungan hidup dan sekitarnya habis terkikis hingga mengakibatkan kerusakan. ${ }^{9}$ Dalam Konferensi Stockholm ini menghasilkan sebuah kesepakatan dimana antara konsep pembangunan dan pengelolaan lingkungan hidup itu sebenarnya saling memiliki keterkaitan. Dimulai dari kemiskinan di suatu negara yang otomatis pertumbuhan ekonominya juga sangat kecil bahkan tidak bertumbuh, kemudian tekanan kependudukan di negara-negara berkembang, pola hidup dan konsumsi warga negara yang sangat berlebihan pada negara maju hingga tidak adanya keseimbangan antar dalam perekonomian nasional yang menjadi penyebab utama permasalahan atau rusaknya lingkungan hidup dunia. ${ }^{10}$

Dewasa ini, permasalahan akan lingkungan hidup bukanlah hal yang baru yang dialami oleh pemerintah Indonesia. Hal ini dibuktikan dengan masih banyaknya sengketa lingkungan

\footnotetext{
6 Ibid, hal. 7

7 Jen Lidya, Kajian Hukum Tentang Penyelesaian Sengketa di Luar Pengadilan Menurut UndangUndang Nomor 32 Tahun 2009 Tentang Perlindungan dan Pengelolaan Lingkungan Hidup, dalam Jurnal Lex Crimen, Vol. 6, No. 6, Agustus 2017, hal. 23

8 Handri Wirastuti dan Rahadi Wasi, Sengketa Lingkungan dan Penyelesaiannya, dalam Jurnal Dinamika Hukum , Vol. 10, No. 2, Mei 2010, hal. 164

9 Syahrul Machmud, Penegakan Hukum Lingkungan, Penegakan Hukum Administrasi, Hukum Perdata dan Hukum Pidana menurut Undang-Undang Nomor 32 Tahun 2009, (Yogyakarta : Graha IImu, 2012), hal. 28

10 Jen Lidya, Op.Cit., hal. 24
} 
yang belum terselesaikan atau belum mendapatkan jalan keluar permasalahannya. Permasalahan yang tak kunjung selesai dikarenakan tidak adanya tindakan nyata dan tegas dari Pemerintah terhadap perusahaan-perusahaan yang secara hukum telah sah terbukti melakukan pencemaran lingkungan hidup. Tidak hanya itu, masih adanya konflik-konflik kepentingan ekonomi, sosial dan lingkungan hidup yang turut menjadi cerminan lemahnya aparat penegak hukum di Indonesia. Beberapa kasus kerusakan lingkungan hidup yang cukup heboh yaitu kasus pada perusahaan pulp PT Inti Indorayon Utama yang diberhentikan operasionalnya akibat terbukti telah melakukan pencemaran lingkungan pada Mei 2000. Tidak hanya sampai disitu, PT Inti Indorayon Utama yang pada 5 April 2003 berubah nama menjadi PT Toba Pulp Lestari Tbk masih terbukti melakukan kebohongan publik terkait dengan limbah kimia yang dihasilkan dari pabrik pulp tersebut. Mereka terbukti telah merusak dan mencemarkan tanah bahkan lingkungan sekitar masyarakat adat setempat. Hingga kini, masyarakat adat setempat masih melakukan penuntutan agar perusahaan tersebut ditutup kegiatan operasionalnya, namun aparat penegak hukum dan pemerintah daerah tidak menunjukkan adanya tindak tegas terhadap PT Toba Pulp Lestari, Tbk.

Apabila ditinjau dengan seksama, pengelolaan lingkungan hidup lebih dominan ditujukan untuk hal-hal yang berhubungan dengan investasi dan tidak dimaknai sebagai suatu ecological and sustainable sense. Kondisi lingkungan hidup dengan ketersediaan sumber daya alam yang baik dan terpenuhi sudah menjadi hak asasi manusia. Hubungan antara hak asasi manusia (HAM) dengan lingkungan hidup menjadi salah satu issue yang dipicu karena semakin meningkatnya pencemaran lingkungan hidup di dunia yang diakibatkan oleh industri-industri yang berkembang pesat dewasa ini. Secara otomatis, kerusakan lingkungan hidup ini akan meniadakan pemenuhan HAM, tidak hanya terbatas pada hak sosial, hak ekonomi, hak budaya namun juga hak politik bahkan sipil warga negara. Dalam kurun waktu 25 tahun Indonesia mengenal hukum lingkungan, pembangunan berkelanjutan yang diharapkan untuk kemakmuran rakyat belum terwujud signifikan. Hal ini ditandai dengan masih banyaknya kasus-kasus pencemaran lingkungan hidup yang belum selesai. Dapat dipastikan, hal ini disebabkan karena regulasi yang masih tumpang tindih, aparat penegak hukum bahkan pejabat pemerintah belum memiliki karakter profesional dan tegas, sistem peradilan yang tidak jelas dan berbelit-belit, hingga dana pendukung penegakan hukum yang masih belum mencukupi. ${ }^{11}$

Berkenaan dengan permasalahan tersebut, dalam rangka meminimalisir pencemaran lingkungan hidup, harus diperlukan kerjasama dari para ahli lingkungan yang berasal dari berbagai displin ilmu guna mendorong dan mewujudkan pembinaan dan pengembangan

11 Handri Wirastuti, dkk, Op.Cit., hal 165 
pembangunan berkelanjutan berwawasan lingkungan. ${ }^{12}$ Menyikapi hal ini, diperlukan suatu wujud nyata tindakan terhadap penyelesaian sengketa lingkungan hidup yang terjadi di Indonesia. Indonesia sendiri mengenal dua sistem penyelesaian sengketa lingkungan hidup yaitu melalui jalur litigasi (lembaga peradilan) dan yang kedua melalui jalur non litigasi (diluar pengadilan).

\section{B. Pembahasan}

\section{Regulasi Terhadap Penyelesaian Sengketa Lingkungan Hidup}

Dalam artian yang sederhana, hukum lingkungan dapat dimaknai sebagai hukum yang menganut tatanan lingkungan hidup, sebagaimana juga yang diamanatkan dalam UndangUndang Nomor 32 Tahun 2009 tentang Perlindungan dan Pengelolaan Hidup (UUPPLH) bahwa hukum lingkungan merupakan hukum yang memiliki hubungan langsung dengan alam dalam arti yang luas. Maka dapat disimpulkan hukum lingkungan adalah intrumen yuridis bagi pengelolaan lingkungan. Koesnadi Hardjasoemantri, berpendapat bahwa dikarenakan pelaku utama pengelolaan lingkungan hidup adalah pemerintah, maka secara otomatis hukum lingkungan merupakan bagian dari hukum pemerintah (bestuursrecht), hukum lingkungan pemerintah (bestuursrechttelijk milleurecht), hukum lingkungan perdata (privaat rechttelijk milleurecht, hukum lingkungan tata negara (staatrechttelijk milleurecht), hukum lingkungan pidana (strafrechttelijk milleurecht) dan bidang hukum lainnya yang berkaitan dengan pengelolaan lingkungan hidup. ${ }^{13}$

Dalam Pasal 1 angka 25 UUPPLH dinyatakan bahwa perselisihan yang terjadi antara dua belah pihak atau lebih yang dipicu oleh kegiatan yang memiliki potensi dan/atau berdampak pada lingkungan dapat dikatakan sebagai suatu sengketa lingkungan hidup. Dalam penyelesaian sengketa lingkunganpun dapat dilakukan melalui prosedur perwakilan atau yang dikenal dengan class action. Lembaga class action ini berkedudukan strategis karena dapat memberikan peluang besar untuk masyarakat kelas ekonomi menengah ke bawah dalam melakukan penuntutan atas apa yang menjadi hak mereka, seperti : hak atas pelayanan kesehatan, hak atas pendidikan yang layak, hak untuk mendapatkan lingkungan yang bersih. ${ }^{14}$ Achmad Santosa berpendapat bahwa penyelesaian sengketa lingkungan hidup merupakan usaha untuk menegakkan hukum terhadap lingkungan hidup melalui berbagai cara dan pendekatan misalnya seperti instrumen ekonomi, pendidikan, bantuan teknis ataupun dengan

12 Siti Sundari Rangkuti, Hukum Lingkungan dan Kebijaksanaan Lingkungan Nasional, (Surabaya : Airlangga University Press, 2000), hal. 3

13 Ibid

14 Sundari, Pengajuan Gugatan Secara Class Action: Suatu Studi Perbandingan \& Penerapannya di Indonesia, (Yogyakarta : Universitas Atma Jaya, 2002), hal. 8 
tekanan publik. Pendekatan yang dimaksud dapat ditempuh melalui Pendekatan Command and Control (CAC), Pendekatan Ekonomi, Pendekatan Perilaku (behaviour), dan Pendekatan Pendayagunaan Tekanan Publik. ${ }^{15}$ Ditegaskan juga pada Undang-Undang Nomor 32 Tahun 2009, penegakan hukum lingkungan terdiri atas tiga kategori, antara lain Penegakan hukum lingkungan administrative, Penegakan hukum lingkungan pidana, dan Penegakan hukum lingkungan perdata. ${ }^{16}$

Sedangkan untuk penegak hukum pada masing- masing aspek terdiri atas Aspek administratif, Aspek Pidana dan Aspek Perdata. Aspek administratif yang terdiri dari pejabat administratif atau pemerintah. Aspek pidana, yakni dimana terjadi penuntutan akibat monopoli yang dilakukan oleh negara dan jaksa sebagai alat personifikasi negara. Aspek perdata, yakni pihak yang mengalami kerugian baik individu ataupun kelompok hingga masyarakat atau negara dengan mengatasnamakan kepentingan umum ${ }^{17}$

Sebagaimana yang telah diatur dalam ketentuan UUPPLH, jika sengketa lingkungan hidup terjadi, maka penegakan hukumnya harus dilakukan secara bertahap berdasarkan prinsip hukum penyelesaiannya, yakni secara administratif, pidana ataupun perdata sesuai dengan yang tercantum pada BAB XIII, baik melalui jalur pengadilan ataupun di luar pengadilan. Penelitian ini, akan terfokus pada pembahasan kritis mengenai mekanisme penyelesaian sengketa lingkungan hidup di luar pengadilan atau yang biasa disebut juga dengan alternative dispute resolution (ADR). Pada umumnya, mekanisme non pengadilan ini menempuh jalan keluar dengan melaksanakan prinsip musyawarah atau kesepakatan antar pihak tergugat dan penggugat.

\section{Mekanisme Penyelesaian Sengketa Lingkungan Hidup melalui Jalur Non Pengadilan (Alternative Dispute Resolution/ ADR)}

Perkembangan mekanisme penyelesaian sengketa lingkungan hidup luar pengadilan atau non litigasi di Indonesia, pada dasarnya diakibatkan karena fakta yang diterima bahwa mekanisme penyelesaian jalur pengadilan atau litigasi cenderung memakan biaya yang cukup besar dan birokrasi pengadilan yang berbelit-belit. Ada beberapa penyebab latar belakang mengapa sistem ini menjadi cukup diminati bagi para pihak yang bersengketa, antara lain Sistem alternative dispute resolution atau ADR dinilai lebih fleksibel dan responsive terhadap kebutuhan para pihak yang bersengketa. Melalui sistem ADR ini, masyarakat semakin dilibatkan perannya dalam hal penyelesaian sengketa. Melalui sistem ADR ini, akses untuk

15 Mas Achmad Santosa, Good Governance \& Hukum Lingkungan, (Jakarta : Indonesian Center for Environment Law (ICEL), 2001), hal. 234

16 Syahrul Machmud, Op.Cit, hal. 163

17 Andi Hamzah, Penegakan Hukum Lingkungan, (Jakarta: Sinar Grafika,2005), hal. 50 
mencapai suatu keadilan lebih besar sehingga nantinya setiap perkara ataupun sengketa memiliki karakter khusus tersendiri. ${ }^{18}$

Terdapat dua pandangan mengenai alternative dispute resolution atau ADR. Pertama, Alternative Dispute Resolution adalah upaya penyelesaian sengketa lingkungan di luar pengadilan, yang dapat berupa arbitrase, negosiasi, mediasi, dan konsiliasi; Kedua, ADR adalah suatu forum untuk menyelesaikan sengketa lingkungan hidup melalui jalur non litigasi dan arbitrase (melalui pihak ketiga); Ketiga, ADR merupakan upaya penyelesaian sengketa lingkungan hidup tidak melalui jalur pengadilan juga tidak hanya sebatas pada arbitrase, negoisasi, dan mekanisme lainnya.

Penyelesaian sengketa lingkungan hidup di luar pengadilan menurut UUPPLH pada dasarnya bersifat sukarela. Hal ini tertuang dalam Pasal 84 ayat (1) UUPPLH yang menyatakan bahwa "Penyelesaian sengketa lingkungan hidup dapat ditempuh melalui pengadilan atau diluar pengadilan“. Hal ini mengartikan bahwa setiap orang diberikan kebebasan untuk memilih mekanisme mana yang akan digunakan dalam penyelesaian sengketa lingkungan dan juga guna melindungi hak-hak keperdataan para pihak yang bersengketa. Akan tetapi, kebebasan yang diberikan ini tidak bersifat mutlak. Artinya masih ada pembatasan, antara lain: Pertama, segala bentuk tindak pidana lingkungan hidup tidak boleh diterapkan mekanisme penyelesaian di luar pengadilan; Kedua, dalam hal kedua belah pihak telah memilih mekanisme penyelesaian sengketa di luar pengadilan, maka secara otomatis sudah tidak dijinkan lagi untuk menggunakan mekanisme penyelesaian lainnya seperti melalui lembaga peradilan.

Adapun tujuan dari mekanisme penyelesaian sengketa di luar pengadilan atau non litigasi ini adalah untuk mencapai suatu kesepakatan akan bentuk dan seberapa besar ganti rugi yang diperoleh, bentuk tindakan pemulihan akibat pencemaran lingkungan hidup, jaminan akan tidak terulang kembali kasus pencemaran lingkungan, dan tindakan yang dilakukan guna mencegah konsekuensi negatif yang timbul terhadap lingkungan hidup dan sekitarnya.

Dengan demikian, mekanisme penyelesaian di luar pengadilan pada dasarnya memiliki tujuan finansial dan non finansial. Tujuan finansial menekankan aspek monetery settlement atau ganti rugi, sedangkan non finansial lebih mengarah pada tindakan tertentu seperti memasang atau memperbaiki Unit Pengelolaan Limbah (UPL sehingga menghasilkan limbah dengan standarisasi Baku Mutu Lingkungan Hidup (BMLH). Berbagai usaha yang dapat dilakukan untuk mencapai kesepakatan itu dapat dilakukan para pihak bersengketa melalui metode negoisasi atau dengan melibatkan pihak ketiga atau yang disebut dengan arbitrase. Para pihak yang bersengketa diberikan kebebasan untuk menentukan mekanisme yang

18 Jackson Oktaryo, Tinjauan Hukum Terhadap Penyelesaian Sengketa Lingkungan Hidup di Luar Pengadilan, dalam Jurnal Ilmiah Advokasi, Vol. 01, No. 02, September 2013, hal. 33 
digunakan dalam menyelesaiakan sengketa lingkungan, sebagaimana yang dimanatkan dalam Pasal 85 ayat (3) UUPLH.

\section{Penyelesaian Sengketa Lingkungan di Luar Pengadilan Berdasarkan Undang- Undang Nomor 30 Tahun 1999}

Undang-Undang Nomor 30 Tahun 1999 tentang Arbitrase dan Alternatif Penyelesaian Sengketa menguraikan beberapa poin penting. Pertama mengenai Alternatif Penyelesaian Sengketa, sebagai suatu metode penyelesaian sengketa melalui prosedur yang telah disepakati antar para pihak yang bersifat mengikat. Adapun prosedur yang dijalankan yaitu melalui jalur di luar pengadilan atau non litigasi. Jalur non litigasi dapat ditempuh dengan beberapa metode, yakni Konsultasi, Negosiasi, Mediasi, Konsiliasi dan Penilaian Para Ahli. ${ }^{19}$

Konsultasi, sebagai suatu metode penyelesaian yang lebih personal antar pihak atau yang biasa disebut dengan klien dengan konsultan, yang dimana si konsultan memberikan pendapat dan saran terhadap kebutuhan si klien, namun konsultan tersebut. Dengan kata lain, konsultan hanya sebatas memberikan pendapat hukum saja, selanjutnya mengenai keputusan jalan keluar akan diputusakan oleh pihak klien.

Negoisasi, sebagai suatu metode penyelesaian dengan cara mendiskusikan permasalahan antara para pihak yang bersengketa untuk menemukan jalan keluar

Mediasi, sebagai suatu metode penyelesaian yang dimana mediator memberikan fasilitas sebagai pihak komunikator dan negosiator antara kedua belah pihak bersengketa untuk menemukan titik temu penyelesaian sengketa. Mediasi biasanya memiliki karakter dimana para pihak bersukarela bersedia menyelesaikan sengketa secara musyawarah dengan pertolongan mediator, pihak mediator harus bersifat netral atau tidak memihak siapapun, mediator tidak memiliki wewenang untuk memutuskan hasil diskusi atau kesepakatan, hanya sebatas membantu para pihak bersengkata menemukan solusi sengketa, dan terakhir seluruh pihak memiliki tujuan yang sama yaitu mencapai kesepakatan. ${ }^{20}$ Terhadap mekanisme ini, Syahrizal Abbas mengemukakan terkait keberadaan mediator sebagai penengah berarti harus berada pada posisi netral serta tidak memihak siapapun dalam usaha penyelesaian sengketa. Mediator harus mampu menjaga kepentingan para pihak bersengketa dengan adil dan seimbang, serta membangun kepercayaan antar para pihak. ${ }^{21}$

19 Frans Hendra Winarta, Hukum Penyelesaian Sengketa: Arbitrase Nasional Indonesia dan Internasional, (Jakarta: Sinar Grafika, 2011), hal. 7

20 Jackson Oktaryo, Op. Cit, hal. 36

21 Syahrizal Abbas, Mediasi dalam Perspektif Hukum Syariah, Hukum Adat dan Hukum Nasional, (Jakarta: Kencana, 2011), hal. 2 
Konsiliasi, sebagai suatu metode penyelesaian sengketa lingkungan dengan mengikutsertakan pihak ketiga yang bersifat netral guna membantu para pihak bersengketa dalam menemukan penyelesaian yang telah disetujui para pihak. Perbedaan nya dengan mediator, pihak ketiga ini bersifat pasif atau hanya sebatas pada fungsional prosedural saja, sedangkan mediator berperan secara aktif dalam membantu menyelesaikan sengketa lingkungan.

Penilaian dari Para Ahli, yaitu pendapat hukum yang bersifat mengikat dari lembaga arbitrase. Sebagaimana dalam ketentuan Pasal 52 Undang-Undang Arbitrase dan Alternatif Penyelesaian Sengketa, para pihak memiliki hak untuk mengajukan pendapat yang mengikat dari lembaga arbitrase atas hubungan hukum tertentu dari suatu perjanjian.

Poin penting lainnya pada Undang-Undang Nomor 30 Tahun 1999 tentang Arbitrase dan Alternatif Penyelesaian Sengketa,yakni mengenai Arbitrase. Pasal 1 angka 1 Undang-Undang Nomor 30 Tahun 1999 secara tegas membatasi kedudukan arbitrase sebagai cara penyelesaian sengketa perdata diluar peradilan umum berdasarkan perjanjian arbitrase secara tertulis oleh para pihak yang bersengketa. Jika dibandingan dengan metode seperti negoisasi, mediasi, atau konsiliasi, arbitrasi merupakan metode yang lebih formal. Penyelesaian sengketa melalui arbitrase tidak lebih terjamin karena ditangani oleh arbitrator yang terpilih berdasarkan keahlian yang dimiliki serta dapat menjamin kerahasiaan para pihak yang bersengketa. Adapun kelemahan mekanisme arbitrase ini antara lain cenderung memakan biaya yang cukup besar, hal ini dikarenakan piak yang bersengketa diwajibkan membiayai segala keperluan penyelesaian sengketa dari awal dimulai dari honor arbiter, biaya sewa ruangan, biaya kesekretariatan, dan sebagainya. Selain itu, arbitrase yang besifat permanen sangat jarang ditemui karena sebagian besar berada di kota-kota besar. ${ }^{22}$

Lembaga arbitrase biasanya digunakan dalam ruang lingkup lingkungan bisnis serta para pihak yang terlibat telah memiliki kesepakatan melalui suatu sistem klausul perjanjian yang berupa menundukkan diri (submission) dan menyerahkan urusan penyelesaian sengketa kepada pihak ketiga yang benar-benar sudah dipastikan netral. Lembaga arbitrase yang dikenal di Indonesia adalah BANI (Badan Arbitrase Nasional Indonesia). Badan ini memiliki wewenang penuh atas para pihak untuk menyelesaikan sengketa dan keputusan yang dihasilkan bersifat final atau langsung dan banding kepada para pihak. ${ }^{23}$

\footnotetext{
${ }^{22}$ Handri Wirastuti dan Rahadi Wasi, Op.Cit., hal 168

${ }^{23}$ Jackson Oktaryo, Op.Cit, hal 38
} 
Tabel 1.

Perbandingan Keunggulan Antara Mediasi, Arbitrase dengan Jalur Pengadilan (Litigasi) Sumber : Marwah Diah, 2008

\begin{tabular}{|c|c|c|c|}
\hline Proses & Mediasi & Arbitrase & Litigasi \\
\hline Pihak yang mengatur & Para pihak parties & Arbitrator & Hakim \\
\hline Prosedur & Informal & $\begin{array}{l}\text { Agak formal sesuai } \\
\text { dengan peraturan } \\
\text { berlaku }\end{array}$ & Formalistik teknis \\
\hline Jangka Waktu & 3-6 minggu & 3-6 bulan & 5-12 tahun \\
\hline Biaya & Sangat murah & Relatif mahal & Sangat mahal \\
\hline Aturan Pembuktian & Tidak perlu & $\begin{array}{l}\text { Agak informal dan } \\
\text { tidak teknis }\end{array}$ & $\begin{array}{l}\text { Sangat formal dan } \\
\text { teknis }\end{array}$ \\
\hline Publikasi & $\begin{array}{l}\text { Confidential dan } \\
\text { pribadi }\end{array}$ & $\begin{array}{l}\text { Confidential dan } \\
\text { pribadi }\end{array}$ & $\begin{array}{l}\text { Terbuka untuk } \\
\text { umum }\end{array}$ \\
\hline Hubungan para pihak & Sangat kooperatif & Tidak kooperatif & Tidak kooperatif \\
\hline Proses Negoisasi & $\begin{array}{l}\text { Berlaku kompromi } \\
\text { antar para pihak }\end{array}$ & $\begin{array}{l}\text { Keras dan kokoh } \\
\text { terhadap prinsip } \\
\text { hukum }\end{array}$ & $\begin{array}{l}\text { Keras dan kokoh } \\
\text { terhadap prinsip } \\
\text { hukum }\end{array}$ \\
\hline Komunikasi & $\begin{array}{l}\text { Memperbaiki masa } \\
\text { lalu }\end{array}$ & $\begin{array}{l}\text { Menghadapi jalan } \\
\text { buntu }\end{array}$ & $\begin{array}{l}\text { Menghadapi jalan } \\
\text { buntu }\end{array}$ \\
\hline Hasil & Seimbang- Menang & Kalah- Menang & Kalah-Menang \\
\hline Performance & Secara sukarela & Emosional & Emosi bergejolak \\
\hline
\end{tabular}

\section{Simpulan}

Penyelesaian sengketa lingkungan hidup dapat ditempuh melalui jalur litigasi dan non litigasi, dengan mengacu sebab akibat pada hak-hak masyarakat yang dirugikan sebagai pihak penggugat akibat adanya suatu kegiatan industri ataupun eksploitasi sumber daya alam yang tanpa memperhatikan kualitas dan kelestarian lingkungan sekitarnya. Penyelesaian sengketa melalui ADR atau alternative dispute resolution dapat dijadikan solusi utama dalam segala penyelesaian sengketa yang berkaitan dengan lingkungan hidup karena lebih bersifat informalitas, tidak memakan waktu yang lama serta melalui diskusi atau musyawarah guna mencapai kesepakatan. Meskipun mekanisme penyelesaian sengketa lingkungan hidup diluar pengadilan masih memiliki banyak kelemahan, kendati demikian mekanisme ini masih 
merupakan bagian dari kebijakan perlindungan dan pengelolaan lingkungan hidup di Indonesia yang mendukung terciptanya pembangunan berkelanjutan berwawasan lingkungan.

\section{DAFTAR PUSTAKA}

Buku:

Abbas, Syahrizal Mediasi dalam Perspektif Hukum Syariah, Hukum Adat dan Hukum Nasional, Jakarta: Kencana, 2011

Asshiddiqie, Jimly, Green Constitution (Nuansa Hijau Undang Undang Dasar Negara Republik Indonesia Tahun 1945), Jakarta : Rajagrafindo Persada, 2009

Hamzah, Andi Penegakan Hukum Lingkungan, Jakarta: Sinar Grafika,2005

Machmud,Syahrul Penegakan Hukum Lingkungan, Penegakan Hukum Administrasi, Hukum Perdata dan Hukum Pidana menurut Undang-Undang Nomor 32 Tahun 2009, Yogyakarta : Graha IImu, 2012

Muhjad, Hadin Hukum Lingkungan : Sebuah Pengantar untuk Konteksi Indonesia, Yogyakarta : Genta Publishing, 2015

Najd, E. Shobirin et al, Diseminasi Hak Asasi Manusia, Perspektif dan Aksi, Jakarta: Cesta LP3ES, 2000

Rangkuti, Siti Sundari, Hukum Lingkungan dan Kebijaksanaan Lingkungan Nasional, Surabaya : Airlangga University Press, 2000

Rasjidi, Lili dan I.B. Wyasa Putra, Hukum sebagai Suatu Sistem, (Bandung: CV. Mandar Maju, 2003)

Santosa, Mas Achmad, Good Governance \& Hukum Lingkungan, Jakarta : Indonesian Center for Environment Law (ICEL), 2001

Soemarwoto, Otto, Analisis Mengenai Dampak Lingkungan, Yogyakarta: Gajahmada University Press, 2003

Sundari, Pengajuan Gugatan Secara Class Action: Suatu Studi Perbandingan \& Penerapannya di Indonesia, Yogyakarta : Universitas Atma Jaya, 2002

Winarta, Frans Hendra, Hukum Penyelesaian Sengketa: Arbitrase Nasional Indonesia dan Internasional, Jakarta: Sinar Grafika, 2011

\section{Jurnal:}

Diah, Marwah, Prinsip dan Bentuk-Bentuk Alternatif Penyelesaian Sengketa di Luar Pengadilan, dalam Jurnal Hukum dan Dinamika Masyarakat, Vol. 5, No. 2, April 2008

Kasim, Ifdhal Hak atas Lingkungan Hidup dan Tanggung Gugat Korporasi Internasional, dalam Jurnal SUAR, Vol. 5, No. 10

Lidya, Jen, Kajian Hukum Tentang Penyelesaian Sengketa di Luar Pengadilan Menurut Undang-Undang Nomor 32 Tahun 2009 Tentang Perlindungan dan Pengelolaan Lingkungan Hidup, dalam Jurnal Lex Crimen, Vol. 6, No. 6, Agustus 2017 
Oktaryo, Jackson, Tinjauan Hukum Terhadap Penyelesaian Sengketa Lingkungan Hidup di Luar Pengadilan, dalam Jurnal Ilmiah Advokasi, Vol. 01, No. 02, September 2013

\section{Peraturan Perundang-undangan:}

Undang-Undang Dasar Negara Republik Indonesia Tahun 1945

UU Nomor 30 Tahun 1999 tentang Arbitrase dan Alternatif Penyelesaian Sengketa, LN No. 138, TLN No. 3872

UU Nomor 32 Tahun 2009 tentang Perlindungan dan Pengelolaan Lingkungan Hidup, LN No. 140, TLN No. 5059 